\title{
Insoluble calcium content and rheological properties of Colby cheese during ripening
}

\author{
M.-R. Lee, ${ }^{*}$ M. E. Johnson,† S. Govindasamy-Lucey,† J. J. Jaeggi,† and J. A. Lucey*1 \\ ${ }^{*}$ Department of Food Science, and \\ †Wisconsin Center for Dairy Research, University of Wisconsin-Madison, 1605 Linden Drive, Madison 53706
}

\section{ABSTRACT}

Colby cheese was made using different manufacturing conditions (i.e., varying the lactose content of milk and $\mathrm{pH}$ values at critical steps in the cheesemaking process) to alter the extent of acid development and the insoluble and total $\mathrm{Ca}$ contents of cheese. Milk was concentrated by reverse osmosis (RO) to increase the lactose content. Extent of acid development was modified by using high (HPM) and low (LPM) $\mathrm{pH}$ values at coagulant addition, whey drainage, and curd milling. Total Ca content was determined by atomic absorption spectroscopy, and the insoluble (INSOL) Ca content of cheese was measured by the cheese juice method. The rheological and melting properties of cheese were measured by small amplitude oscillatory rheometry and UW-Melt Profiler, respectively. There was very little change in $\mathrm{pH}$ during ripening even in cheese made from milk with high lactose content. The initial (d 1) cheese pH was in the range of 4.9 to 5.1. The INSOL Ca content of cheese decreased during the first $4 \mathrm{wk}$ of ripening. Cheeses made with the LPM had lower INSOL Ca content during ripening compared with cheese made with HPM. There was an increase in melt and maximum loss tangent values during ripening except for LPM cheeses made with RO-concentrated milk, as this cheese had $\mathrm{pH}<4.9$ and exhibited limited melt. Curd washing reduced the levels of lactic acid produced during ripening and resulted in significantly higher INSOL Ca content. The use of curd washing for cheeses made from high lactose milk prevented a large $\mathrm{pH}$ decrease during ripening; high rennet and draining $\mathrm{pH}$ values also retained more buffering constituents (i.e., INSOL Ca phosphate), which helped prevent a large $\mathrm{pH}$ decrease.

Key words: calcium, colloidal calcium phosphate, cheese functionality, casein interaction

Received September 15, 2009.

Accepted January 14, 2010.

${ }^{1}$ Corresponding author: jalucey@facstaff.wisc.edu

\section{INTRODUCTION}

Curd washing is commonly used in the manufacture of Muenster, Brick, Colby (i.e., washed-curd Cheddar), and lower fat cheeses for various technical purposes. The method of washing, the temperature and amount of wash water, and washing time are varied in these cheese varieties (Van Slyke and Price, 1949; Wilson and Reinbold, 1965; Kosikowski and Mistry, 1997). Curd washing takes place after the whey is drained and the desired $\mathrm{pH}$ of the curd has been attained. The curd is kept from matting and is continuously stirred. Curd is sometimes washed with cold water to increase the moisture content as well as to remove lactose from the curd (Kosikowski and Mistry, 1997). Washed-curd Colby cheese is generally higher in moisture, softer, and has a more open texture than milled-curd Cheddar cheese (Wilson and Reinbold, 1965; Kosikowski and Mistry, 1997). In Gouda and Edam cheese, approximately 20 to $45 \%$ of whey is drained after the coagulum is cut. Warm water $\left(\sim 35^{\circ} \mathrm{C}\right)$ is added after cutting (this procedure is also called scalding) and the curd/water mixture is stirred for about $25 \mathrm{~min}$ (Walstra et al., 2006). The purpose of whey dilution in Dutch-type cheese is to regulate the $\mathrm{pH}$ of cheese independently of its moisture content. A curd-washing or whey dilution step during cheese manufacturing decreases the amount of acid in cheese. Curd washing can affect the $\mathrm{pH}$ of cheese (Van Den Berg and De Vries, 1974; Huffman and Kristoffersen, 1984; Lolkema, 1994; Fox et al., 2000; ShakeelUr-Rehman et al., 2004).

The Ca content of cheese, especially the proportion of soluble and insoluble (INSOL) Ca, plays an important role in determining the functional properties of cheese (Lucey and Fox, 1993; Johnson and Lucey, 2006). Much of the residual Ca in cheese $(\mathrm{pH}>4.9)$ is still associated with casein and is described as INSOL Ca (Monib, 1962; Lucey and Fox, 1993). There is a decrease in the INSOL Ca content of Cheddar cheese during ripening and this contributes to age-related changes in the textural and rheological properties (Hassan et al., 2004; Lucey et al., 2005; O'Mahony et al., 2005). Age-related changes in the Ca equilibrium have 
been observed in other cheese varieties (e.g., Thierry et al., 1998; Metzger et al., 2001). However, there are only a limited number of studies regarding changes in the $\mathrm{Ca}$ equilibrium in cheese made by altering the lactose content of milk. Lee et al. (2005) investigated the effect of using lower than normal manufacturing $\mathrm{pH}$ values on the $\mathrm{Ca}$ equilibrium of Cheddar cheese made from milk with normal or elevated lactose contents. Lee et al. (2005) reported that Cheddar cheese that had very low $\mathrm{pH}(<4.94)$ resulted in cheese with a low meltability and a brittle/short texture. Even in cheese that attained a very low pH (e.g., 4.67) during ripening, the INSOL Ca content only decreased to $\sim 47 \%$ (as a percentage of total $\mathrm{Ca}$ ) during ripening. In milk, all INSOL Ca would have dissolved at such a low $\mathrm{pH}$ value (Pyne and McGann, 1960). Evidently, the effect of $\mathrm{pH}$ on the Ca equilibrium in cheese is not identical to the situation observed in milk (Johnson and Lucey, 2006).

We are not aware of any studies on the effect of curd washing on the Ca equilibrium of cheese during ripening. We believe that washing not only alters acid development during cheese making and ripening but also modifies the Ca equilibrium by the removal of acid and soluble salts. Washing has been shown to alter the residual lactose and moisture contents of cheese, which determines the amount of acid that can potentially (depending on the salt-in-moisture levels and salt sensitivity of the starter culture) be produced during ripening (Huffman and Kristoffersen, 1984; Shakeel-Ur-Rehman et al., 2004). The Ca content of cheese, $\mathrm{pH}$, and rate and extent of acid development ( $\mathrm{pH}$ history) are interrelated (Lucey and Fox, 1993). The rheological properties of cheese during ripening are likely to be sensitive to any alteration in total Ca content (Guinee et al., 2002 ) as well as changes in the proportion of INSOL Ca (Lucey et al., 2005; Lee et al., 2005).

Cheeses with high manufacturing $\mathrm{pH}$ values should retain more buffering capacity (such as INSOL Ca phosphate), which should help to prevent low $\mathrm{pH}$ during ripening. In contrast, cheese made with low manufacturing $\mathrm{pH}$ values will likely lose more buffering capacity because of increased solubility of INSOL Ca phosphate at the lower $\mathrm{pH}$ values used during cheese making, and this cheese could attain lower $\mathrm{pH}$ values during ripening.

In this study, the lactose content of milk was varied using concentration by reverse osmosis (RO), curd was washed, and critical $\mathrm{pH}$ values during cheesemaking were varied to modify the soluble components in milk as well as the total $\mathrm{Ca}$ content. The effect of these changes on the $\mathrm{Ca}$ equilibrium and functional properties of Colby cheese was investigated.

\section{MATERIALS AND METHODS}

\section{Reverse Osmosis of Milk}

Reverse osmosis of whole milk was performed as described by Lee et al. (2005). Reverse osmosis was used to remove water and increase the total solids and lactose content of milk. The total solids content of whole milk was increased up to approximately $14 \%$ by RO. Reverse osmosis was performed in the pilot plant of University of Wisconsin-Madison before cheese making. The RO unit was fitted with 2 parallel spiral-wound elements, which were composed of thin film composites. Each element had a membrane area of $7.4 \mathrm{~m}^{2}$ and typical $\mathrm{NaCl}$ rejection of $99.5 \%$ (PTI Advanced Filtration, Oxford, CA). The outlet pressure of RO unit was approximately $1,655 \mathrm{kPa}$, and the operating temperature was kept at approximately $4^{\circ} \mathrm{C}$. Both $\mathrm{RO}$ milk concentrate and nonconcentrated whole milk (NONRO; for making the control Colby cheese) were pasteurized at $73^{\circ} \mathrm{C}$ for $15 \mathrm{~s}$ and cooled to $4^{\circ} \mathrm{C}$.

\section{Cheese Manufacturing}

Two types of manufacturing protocols were used to prepare full fat, washed-curd Colby cheese, described as high pH method (HPM) and low pH method (LPM); cheeses were made from both RO and NONRO milks. The detailed make procedures for the cheeses from RO and NONRO treatments are shown in Table 1. The weight of cheese obtained from each vat was approximately $18 \mathrm{~kg}$. The HPM cheese had higher $\mathrm{pH}$ values at the renneting, draining, and washing steps compared with the LPM cheese (Table 1). Three cheese trials from RO milk and another 3 cheese trials from NONRO milk were performed over an 18-mo period. Cheeses were made by licensed cheese makers at the University of Wisconsin-Madison Dairy Plant (Madison). The LPM cheeses took longer to reach a specific step in the process to allow sufficient time to reach the desired (lower) $\mathrm{pH}$ values. The total elapsed time to reach a target $\mathrm{pH}$ was similar in both RO and NONRO treatments for each individual type of manufacturing protocol.

A mixed-strain starter culture consisting of Lactococcus lactis ssp. cremoris and Lactococcus lactis ssp. lactis was inoculated into the milk with the rate of 1,490 $\mathrm{g} / 226 \mathrm{~kg}$ of milk. Double-strength chymosin (Chymostar, Danisco, Madison, WI) was added at $32^{\circ} \mathrm{C}$ and its strength in international milk clotting units (IDF, 1997) was $250 \mathrm{~mL}^{-1}$. The coagulum was cut with a $0.63-\mathrm{cm}$ knife, and the curd was given a 5 -min healing time before gentle agitation for 10 to $15 \mathrm{~min}$. The curd-whey mixture was heated slowly from 32 to $39^{\circ} \mathrm{C}$ 
Table 1. Cheese manufacturing protocol for Colby cheese $(\mathrm{n}=3$; means $\pm \mathrm{SD})$ made from milk concentrated by reverse osmosis (RO) and nonconcentrated milk (NONRO)

\begin{tabular}{|c|c|c|c|c|}
\hline \multirow[b]{2}{*}{ Treatment } & \multicolumn{2}{|c|}{ High pH method (HPM) } & \multicolumn{2}{|c|}{ Low pH method (LPM) } \\
\hline & $\begin{array}{l}\text { Total elapsed } \\
\text { time (min) }\end{array}$ & $\mathrm{pH}$ & $\begin{array}{l}\text { Total elapsed } \\
\text { time (min) }\end{array}$ & $\mathrm{pH}$ \\
\hline \multicolumn{5}{|l|}{ RO treatment } \\
\hline Initial milk & 0 & $6.58 \pm 0.02$ & 0 & $6.58 \pm 0.02$ \\
\hline Add starter & 0 & $6.57 \pm 0.04$ & 0 & $6.58 \pm 0.02$ \\
\hline Add coagulant & $25 \pm 17$ & $6.52 \pm 0.02$ & $118 \pm 12$ & $6.37 \pm 0.05$ \\
\hline Cut & $45 \pm 15$ & $6.51 \pm 0.02$ & $132 \pm 10$ & $6.35 \pm 0.02$ \\
\hline First drain & $112 \pm 16$ & $6.24 \pm 0.02$ & $187 \pm 10$ & $5.71 \pm 0.06$ \\
\hline Add water & $117 \pm 16$ & $6.24 \pm 0.02$ & $198 \pm 18$ & $5.43 \pm 0.08$ \\
\hline Second drain & $132 \pm 16$ & $6.24 \pm 0.02$ & $213 \pm 18$ & $5.43 \pm 0.08$ \\
\hline Add salt & $178 \pm 20$ & $5.84 \pm 0.12$ & $247 \pm 23$ & $5.14 \pm 0.04$ \\
\hline \multicolumn{5}{|c|}{ NONRO treatment } \\
\hline Initial milk & 0 & $6.57 \pm 0.05$ & 0 & $6.58 \pm 0.04$ \\
\hline Add starter & 0 & $6.56 \pm 0.05$ & 0 & $6.56 \pm 0.03$ \\
\hline Add coagulant & 15 & $6.55 \pm 0.02$ & $108 \pm 3$ & $6.40 \pm 0.01$ \\
\hline Cut & $43 \pm 2$ & $6.51 \pm 0.02$ & $127 \pm 1$ & $6.36 \pm 0.05$ \\
\hline First drain & $105 \pm 23$ & $6.24 \pm 0.03$ & $188 \pm 6$ & $5.64 \pm 0.09$ \\
\hline Add water & $122 \pm 8$ & $6.29 \pm 0.04$ & $193 \pm 6$ & $5.46 \pm 0.08$ \\
\hline Second drain & $137 \pm 8$ & $6.29 \pm 0.04$ & $208 \pm 6$ & $5.46 \pm 0.08$ \\
\hline Add salt & $183 \pm 13$ & $5.84 \pm 0.15$ & $248 \pm 15$ & $5.13 \pm 0.02$ \\
\hline
\end{tabular}

and then continuously stirred at $39^{\circ} \mathrm{C}$ until the desired $\mathrm{pH}$ of curd was reached: approximately 6.2 and $5.6-5.7$ (ranges: 6.24 and 5.64-5.71) for HPM and LPM cheeses, respectively.

All of the whey was then drained and approximately $38 \mathrm{~kg}$ of cold water $\left(\sim 5^{\circ} \mathrm{C}\right)$ was added to the curds. Curds were held in this cold water for $15 \mathrm{~min}$ without any stirring and then the water was completely drained. The curd was dry stirred until the $\mathrm{pH}$ reached $\sim 5.8$ and $\sim 5.1$ for HPM and LPM cheese, respectively. Curd was salted at the rate of $0.72 \mathrm{~kg} / 226 \mathrm{~kg}$ of milk. Salted curd was packed in 9-kg Wilson-style hoops and pressed at $276 \mathrm{kPa}$ for $4 \mathrm{~h}$ at ambient temperature before vacuum packaging. After vacuum packaging, the cheese was stored at $6^{\circ} \mathrm{C}$ for ripening.

\section{Compositional Analysis}

All compositional tests were done in duplicate. Milk was analyzed for total solids, casein, fat, and protein contents (Marshall, 1992). Rennet whey was made from cheese milk on the same day of cheese making by adding the same rennet concentration to milk at $32^{\circ} \mathrm{C}$; after $40 \mathrm{~min}$ the curd was cut with a knife and then centrifuged at $1,000 \times g$. The supernatant was rennet whey. The total Ca of milk and rennet whey was measured by atomic absorption spectroscopy (IDF, 2003). Cheese was analyzed for moisture, fat, protein (Marshall, 1992), pH 4.6 soluble nitrogen (Kuchroo and Fox, 1982), and total Ca (IDF, 2003). The salt content of cheese was measured by chloride analysis (Marshall, 1992). Cheese $\mathrm{pH}$ was measured by the quinhydrone method (Marshall, 1992), and the INSOL Ca contents of cheese were analyzed by the juice method (Hassan et al., 2004) after $1 \mathrm{~d}, 1 \mathrm{wk}, 2 \mathrm{wk}, 3 \mathrm{wk}, 1 \mathrm{mo}$, and 3 mo. Buffering in cheese was determined by acid-base titration (Hassan et al., 2004), and apparent buffering capacity was reported as the volume of $0.5 \mathrm{~N} \mathrm{HCl}$ needed to decrease the $\mathrm{pH}$ of a cheese dispersion by 1.0 $\mathrm{pH}$ unit from initial $\mathrm{pH}$ of the cheese dispersion $(8 \mathrm{~g}$ of cheese/40 g of water; Lee et al., 2005). We use the term "apparent buffering capacity" because the initial $\mathrm{pH}$ values of our cheeses were different.

\section{Melt Profile Analysis}

Melt and flow behavior of cheese samples were evaluated using the UW-Melt Profiler at Wisconsin Center for Dairy Research (Muthukumarappan et al., 1999). Changes in cheese height as a function of cheese temperature were measured until cheese temperature reached $62^{\circ} \mathrm{C}$. At least 4 replicates were performed, and degree of flow (DOF) was calculated as described by Lee et al. (2005).

\section{Dynamic Small Amplitude Oscillatory Rheometry}

The viscoelastic properties of cheese were determined using a Paar Physica universal dynamic spectrometer (UDS 200 Physica Messtechnik, Stuttgart, Germany) using dynamic small amplitude oscillatory rheometry (SAOR). The procedure described by Lee et al. (2005) was followed. The rheological parameters, including storage modulus $\left(\mathbf{G}^{\prime}\right)$ or stiffness, loss modulus $\left(\mathbf{G}^{\prime \prime}\right)$, 
and loss tangent $(\mathbf{L T})$, which is the ratio between the viscous and the elastic properties of the material (LT $\left.=\mathrm{G}^{\prime \prime} / \mathrm{G}^{\prime}\right)$, were determined from SAOR tests. At least 3 replicates were measured for each cheese sample at each time point.

\section{Texture Measurements}

Uniaxial compression tests were performed using a TA.XT2 Texture Analyzer (Texture Technologies Corp., Scarsdale, NY). Cheese samples were prepared as recommended by the International Dairy Federation draft standard for uniaxial compression of cheese (IDF, 2005). The method recently described by Lee et al. (2005) was used.

\section{Statistical Analysis}

Data were analyzed using SAS software version 8.2 (SAS Institute, 2001). Experimental effects of lactose content (RO and NONRO treatments), manufacturing $\mathrm{pH}$ protocols (HPM and LPM methods), and week (aging time) on the INSOL Ca content were evaluated using the Proc MIXED procedure for repeated measurement of SAS. Effects included method, manufacturing $\mathrm{pH}$, week, and method $\times$ week, week $\times$ manufacturing $\mathrm{pH}$, and method $\times$ week $\times$ manufacturing $\mathrm{pH}$ interactions. The least mean squares for cheese, nested within method and manufacturing $\mathrm{pH}$, was used as random error term to test method and manufacturing $\mathrm{pH}$. Fisher's protected least significant difference test was used to compare means and differences between means were considered significant at $P<0.05$. Pearson correlation coefficients were estimated between the various responses (i.e., INSOL Ca, rheological parameters, and DOF).

\section{RESULTS AND DISCUSSION}

\section{Chemical Composition of Milk and Cheese}

The composition of cheese milk and cheese made from the different treatments is shown in Table 2. As expected, RO milk had significantly higher solids, casein, lactose, and total and soluble Ca contents than NONRO milk. There were no statistically significant differences in the fat, salt, protein, and salt-in-moisture contents of cheeses in any of the treatments (Table 2). There was variation in the concentrations of moisture and fat between trials and replicates (trials were performed over a period of more than $1 \mathrm{yr}$ ). The moisture content of LPM cheese made from RO milk was lower than that of HPM cheese made from NONRO milk; the other treatments were not significantly different from each other.

At $1 \mathrm{~d}$, HPM cheese made from RO milk had significantly higher lactose content compared with NONRO cheeses made with this HPM protocol, presumably because of the higher starting lactose content in RO milk (Table 2). Cheeses made from milk with high lactose contents generally have substantial residual lactose (Huffman and Kristoffersen, 1984; Shakeel-Ur-Rehman et al., 2004; Lee et al., 2005). Because of the curdwashing step, lactose was removed during manufacturing and there was a relatively small amount of residual $(1 \mathrm{~d})$ lactose left in cheese; that is, 0.0 to $0.2 \%$ and 0.4 to $0.5 \%$ for cheeses made from NONRO and RO milks, respectively. In typical Cheddar cheese, the lactose content of cheese at $1 \mathrm{~d}$ is usually between 0.4 and $0.8 \%$ (Fox et al., 2000). The lactic acid levels at 2 and $12 \mathrm{wk}$ were significantly higher in the cheese from RO milk compared with the cheese from NONRO milk (Table 2 ). Because of the reduction in the residual lactose content in cheese as a result of curd-washing, the level of lactic acid in cheese at $2 \mathrm{wk}$ (Table 2) was lower (1.2 to $1.4 \%)$ compared with the lactic acid level $(\sim 1.6 \%)$ of unwashed cheeses that had similar manufacturing $\mathrm{pH}$ values (Lee et al., 2005). Washing of curd was able to alter the residual lactose content and this decreased the formation of lactic acid.

\section{Cheese $\mathrm{pH}$}

The $\mathrm{pH}$ values of HPM and LPM cheeses from both treatments ranged from 5.0 to 5.2 and 4.8 to 5.0 , respectively (Figure 1). Cheese $\mathrm{pH}$ did not change significantly during ripening (Figure 1). The $\mathrm{pH}$ values of HPM cheeses made from RO or NONRO milk were significantly higher than the $\mathrm{pH}$ values of the corresponding LPM cheeses (Figure 1). The higher $\mathrm{pH}$ of HPM cheeses could be because of higher $\mathrm{pH}$ values at rennet and whey drainage, which helped to retain more buffering constituents compared with the LPM cheese (Table 2). For a similar manufacturing method, cheeses made from $\mathrm{RO}$ milk always had lower $\mathrm{pH}$ values than cheeses made from NONRO milk (Figure 1). The higher lactose content in RO milks (Table 2) contributed to lower cheese $\mathrm{pH}$ values because of the higher residual lactose content and the formation of higher lactic acid levels (Thomas and Pearce, 1981) compared with cheese made with NONRO milk (Table 2). Cheese $\mathrm{pH}$ changes during ripening are affected by the lactose content of milk or whey (Huffman and Kristoffersen, 1984; Shakeel-Ur-Rehman et al., 2004; Lee et al., 2005), cheese manufacturing $\mathrm{pH}$ values (Lee et al., 2005), salt content (Upreti and Metzger, 2007), and starter activ- 
ity (Swearingen et al., 2004). In cheese milks with high lactose levels (RO milks), curd washing removed much of the lactose and lactic acid, resulting in no significant change in $\mathrm{pH}$ post-manufacture (Figure 1).

\section{Calcium Equilibrium Changes in Cheese}

Total Ca contents of HPM cheeses made from RO or NONRO milk were significantly higher than those of the corresponding LPM cheeses (Table 2). Higher pH at drain results in higher total $\mathrm{Ca}$ content compared with cheese manufactured with lower $\mathrm{pH}$ at drain (Yun et al., 1995). Although RO milk had higher total Ca content than NONRO milk, only the manufacturing method influenced the total Ca content of cheese (Table 2).

In all cheeses, the INSOL Ca content at d 1 was significantly higher than that after 3 mo of ripening (Table 2). The INSOL Ca content of all cheeses decreased during ripening and most of this decrease occurred during the first month of ripening (Figure 2; Table 2). Changes in INSOL Ca content of cheese during ripening were significantly $(P<0.001)$ affected by cheese manufacturing $\mathrm{pH}$ (i.e., HPM or LPM) but not by milk treatment (i.e., RO or NONRO; Table 3). Lower $\mathrm{pH}$ values resulted in greater solubilization of INSOL Ca phosphate. Ripening time (week) signifi-

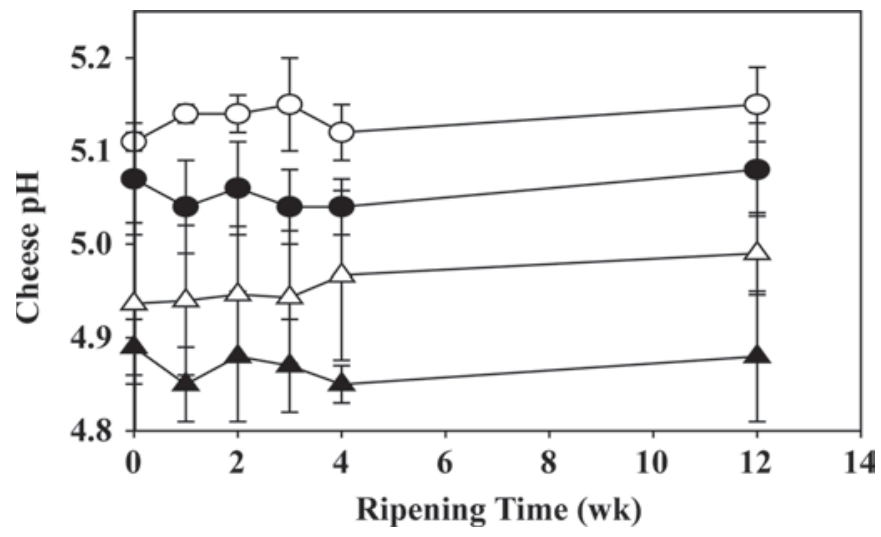

Figure 1. Changes in $\mathrm{pH}$ of Colby cheese by using the RO, high $\mathrm{pH}$ method $(\bullet)$; the RO, low $\mathrm{pH}$ method $(\boldsymbol{\Delta})$; the NONRO, high $\mathrm{pH}$ method $(O)$; and the NONRO, low $\mathrm{pH}$ method $(\Delta)$ as a function of ripening time. The data represent the means $(n=3)$ and the error bars represent the standard deviations for each time point. $\mathrm{RO}=$ milk concentrated by reverse osmosis; NONRO = milk not concentrated before cheese making.

cantly influenced $(P<0.001)$ the INSOL Ca content of cheese, which agrees with previous studies on Cheddar cheese (Hassan et al., 2004; Lucey et al., 2005; Lee et al., 2005).

The INSOL Ca content of cheese initially $(1 \mathrm{~d})$ and during ripening was significantly higher in the HPM

Table 2. Composition of milks and Colby cheeses (means $\pm \mathrm{SD}$ ) made from milk concentrated by reverse osmosis (RO) and nonconcentrated milk (NONRO)

\begin{tabular}{|c|c|c|c|c|}
\hline Item & \multicolumn{2}{|c|}{ NONRO treatments } & \multicolumn{2}{|c|}{ RO treatments } \\
\hline \multicolumn{5}{|l|}{ Milk } \\
\hline Total solids (\%) & \multicolumn{2}{|c|}{$12.3 \pm 0.3^{\mathrm{b}}$} & \multicolumn{2}{|c|}{$138+0.2^{\mathrm{a}}$} \\
\hline Casein $(\%)$ & \multicolumn{2}{|c|}{$2.40 \pm 0.06^{\mathrm{b}}$} & \multicolumn{2}{|c|}{$2.67+0.07^{\mathrm{a}}$} \\
\hline Lactose $(\%)$ & \multicolumn{2}{|c|}{$4.51 \pm 0.17^{\mathrm{b}}$} & \multicolumn{2}{|c|}{$5.03 \pm 0.14^{\mathrm{a}}$} \\
\hline Total Ca (mg/100 g of milk) & \multirow{2}{*}{\multicolumn{2}{|c|}{$\begin{array}{c}108 \pm 4^{\mathrm{b}} \\
36 \pm 2.9^{\mathrm{b}}\end{array}$}} & \multirow{2}{*}{\multicolumn{2}{|c|}{$\begin{array}{l}130 \pm 10 \\
44 \pm 1.8^{\mathrm{a}}\end{array}$}} \\
\hline Soluble Ca (mg/100 g of milk) & & & & \\
\hline Cheese & $\mathrm{HPM}^{1}$ & $\mathrm{LPM}^{1}$ & HPM & LPM \\
\hline Moisture (\%) & $38.7 \pm 0.4^{\mathrm{a}}$ & $36.6 \pm 1.0^{\mathrm{ab}}$ & $37.9 \pm 1.8^{\mathrm{ab}}$ & $36.2 \pm 0.8^{\mathrm{b}}$ \\
\hline Fat $(\%)$ & $32.5 \pm 0.7^{\mathrm{a}}$ & $34.4 \pm 1.2^{\mathrm{a}}$ & $33.6 \pm 1.2^{\mathrm{a}}$ & $34.5 \pm 1.5^{\mathrm{a}}$ \\
\hline Salt (\%) & $1.6 \pm 0.2^{\mathrm{a}}$ & $1.6 \pm 0.3^{\mathrm{a}}$ & $1.4 \pm 0.0^{\mathrm{a}}$ & $1.5 \pm 0.1^{\mathrm{a}}$ \\
\hline Protein $(\%)$ & $23.6 \pm 0.6^{\mathrm{a}}$ & $23.9 \pm 0.6^{\mathrm{a}}$ & $23.6 \pm 0.6^{\mathrm{a}}$ & $23.9 \pm 0.3^{\mathrm{a}}$ \\
\hline Salt-in-moisture (\%) & $4.2 \pm 0.5^{\mathrm{a}}$ & $4.4 \pm 1.0^{\mathrm{a}}$ & $3.7 \pm 0.2^{\mathrm{a}}$ & $4.1 \pm 0.2^{\mathrm{a}}$ \\
\hline Lactose at $1 \mathrm{~d}(\%)$ & $0.2 \pm 0.1^{\mathrm{bc}}$ & $0.0 \pm 0.0^{\mathrm{c}}$ & $0.5 \pm 0.1^{\mathrm{a}}$ & $0.4 \pm 0.1^{\mathrm{ab}}$ \\
\hline Lactic acid at 2 wk (\%) & $1.2 \pm 0.1^{\mathrm{b}}$ & $1.3 \pm 0.1^{\mathrm{b}}$ & $1.4 \pm 0.0^{\mathrm{a}}$ & $1.4 \pm 0.0^{\mathrm{a}}$ \\
\hline Lactic acid at 12 wk (\%) & $1.3 \pm 0.1^{\mathrm{b}}$ & $1.3 \pm 0.0^{\mathrm{b}}$ & $1.4 \pm 0.1^{\mathrm{a}}$ & $1.4 \pm 0.0^{\mathrm{a}}$ \\
\hline Apparent buffering capacity $(\mathrm{mL})$ at $1 \mathrm{~d}^{2}$ & $3.2 \pm 0.0^{\mathrm{a}}$ & $2.8 \pm 0.0^{\mathrm{b}}$ & $3.1 \pm 0.0^{\mathrm{a}}$ & $2.8 \pm 0.0^{\mathrm{b}}$ \\
\hline Total $\mathrm{Ca}(\mathrm{mg} / 100 \mathrm{~g}$ of cheese) & $684 \pm 53^{\mathrm{a}}$ & $569 \pm 48^{\mathrm{b}}$ & $698 \pm 36^{\mathrm{a}}$ & $552 \pm 11^{\mathrm{b}}$ \\
\hline Insoluble $\mathrm{Ca}$ at $1 \mathrm{~d}^{3}$ & $21.8 \pm 2.4^{\mathrm{a}}$ & $16.2 \pm 2.1^{\mathrm{b}}$ & $20.7 \pm 2.1^{\mathrm{a}}$ & $14.1 \pm 0.9^{\mathrm{b}}$ \\
\hline Insoluble $\mathrm{Ca}$ at $1 \mathrm{wk}^{3}$ & $21.2 \pm 1.3^{\mathrm{a}}$ & $14.8 \pm 1.2^{\mathrm{c}}$ & $19.0 \pm 0.1^{\mathrm{b}}$ & $13.2 \pm 0.4^{\mathrm{c}}$ \\
\hline Insoluble $\mathrm{Ca}$ at $1 \mathrm{mo}^{3}$ & $18.2 \pm 2.5^{\mathrm{a}}$ & $14.1 \pm 0.5^{\mathrm{b}}$ & $18.6 \pm 1.5^{\mathrm{a}}$ & $12.8 \pm 1.2^{\mathrm{b}}$ \\
\hline Insoluble $\mathrm{Ca}$ at $3 \mathrm{mo}^{3}$ & $16.1 \pm 3.2^{\mathrm{a}}$ & $13.9 \pm 0.5^{\mathrm{b}}$ & $17.3 \pm 2.5^{\mathrm{a}}$ & $12.4 \pm 1.3^{\mathrm{b}}$ \\
\hline
\end{tabular}

${ }^{\mathrm{a}-\mathrm{c}}$ Means with different letters in the same row indicate that values were not significantly different $(P<$ $0.05)$.

${ }^{1} \mathrm{HPM}=$ high $\mathrm{pH}$ method; LPM $=$ low $\mathrm{pH}$ method.

${ }^{2}$ The amount of $0.5 \mathrm{~N} \mathrm{HCl}$ solution required to titrate cheese homogenate ( $8 \mathrm{~g}$ of cheese $/ 40 \mathrm{~g}$ of water) from its starting $\mathrm{pH}$ to $1.0 \mathrm{pH}$ unit lower than the initial $\mathrm{pH}$ value.

${ }^{3}$ Milligrams of insoluble $\mathrm{Ca} / \mathrm{g}$ of protein in cheese. 


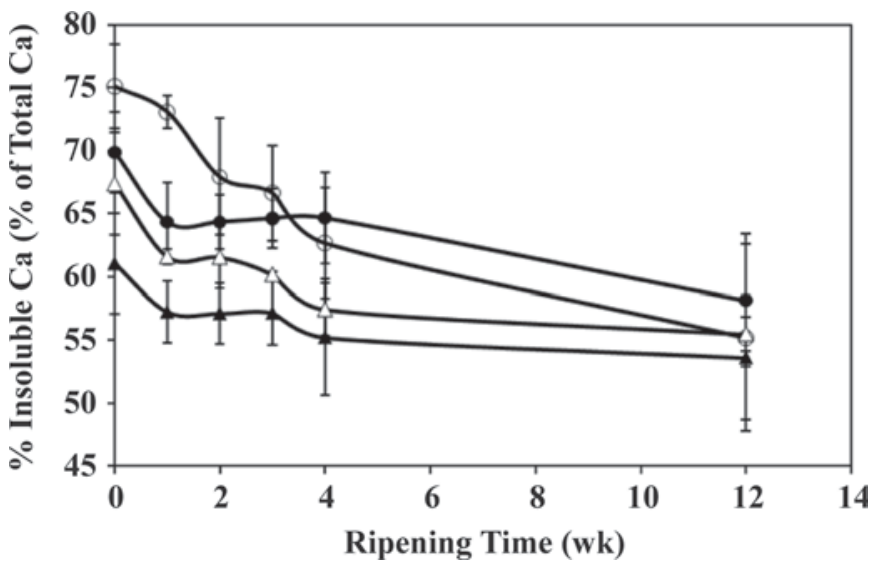

Figure 2. Changes in the percentage insoluble Ca content (percentage of total $\mathrm{Ca}$ ) in Colby cheese made by using the $\mathrm{RO}$, high $\mathrm{pH}$

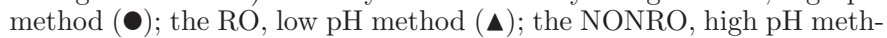
od $(\bigcirc)$; and the NONRO, low $\mathrm{pH}$ method $(\Delta)$. The data represent the means $(\mathrm{n}=3)$ and the error bars represent the standard deviations for each time point. $\mathrm{RO}=$ milk concentrated by reverse osmosis; NONRO $=$ milk not concentrated before cheese making.

cheeses for both RO and NONRO treatments (Table 2). This was presumably because of a greater solubilization of INSOL Ca at the lower $\mathrm{pH}$ values used during cheese making for the LPM cheese (Lucey and Fox, 1993; Lee et al., 2005).

For a similar manufacturing $\mathrm{pH}$ protocol, the INSOL Ca levels were higher in Colby cheese that had a washing step compared with the levels reported for Cheddar (Lee et al., 2005). During ripening, the decrease in INSOL Ca content of LPM Colby cheese made from RO and NONRO milks was much smaller (2.3 and 1.7 $\mathrm{mg} / \mathrm{g}$ of protein, respectively) than that reported by Lee et al. (2005) for LPM Cheddar cheese (3.9 and 3.5 $\mathrm{mg} / \mathrm{g}$ of protein, respectively). The manufacturing $\mathrm{pH}$ treatments used for cheese making in the study of Lee et al. (2005) were similar to those in the current study. The smaller change in the INSOL Ca levels of the Colby cheese during ripening is presumably due to the lack of additional lactic acid formation because there is little lactose left compared with that in Cheddar. In the Cheddar cheese study of Lee et al. (2005) there was a large decrease in $\mathrm{pH}$ during ripening: $1.5 \mathrm{pH}$ units for LPM Cheddar cheese made with RO milk compared with no significant change in cheese $\mathrm{pH}$ for LPM Colby cheese made with RO milk (Figure 1).

It was notable that the INSOL Ca content of all cheeses decreased, whereas $\mathrm{pH}$ showed no significant change during ripening. For example, HPM cheese made from NONRO milk had the highest initial INSOL Ca content as well as the largest decrease in the INSOL Ca content during ripening (Table 2) although the $\mathrm{pH}$ of this cheese hardly changed (Figure 1). This cheese had the highest moisture content (38.7\%; Table 2) and it is possible that this higher moisture content helped to solubilize more INSOL Ca during ripening (by increasing the concentration of the serum phase; Johnson and Lucey, 2006). This result indicates that the decrease in INSOL Ca content of cheese occurs even when there is no reduction in cheese $\mathrm{pH}$ or additional lactic acid formation. A large decrease in cheese $\mathrm{pH}$ during ripening can accelerate the reduction of INSOL $\mathrm{Ca}$ (Lee et al., 2005), but a reduction of INSOL Ca content of cheese can occur even when $\mathrm{pH}$ does not decrease (Hassan et al., 2004). The ongoing solubilization of INSOL $\mathrm{Ca}$ during cheese ripening reflects the attainment of "pseudo-equilibrium" between the INSOL and soluble forms of Ca (Johnson and Lucey, 2006). Washing removed some of the soluble Ca; thus, more INSOL Ca became solubilized during ripening to reach a stable pseudo-equilibrium.

The significantly higher buffering capacity of HPM cheese (Table 2) from both RO and NONRO treatments compared with LPM cheeses was due to the higher INSOL Ca phosphate levels in HPM cheeses because the protein concentration was not significantly different $(P>0.05)$ in any of the cheeses. Proteolysis ( $\mathrm{pH} 4.6$ soluble nitrogen levels) determined at 3 mo was slightly higher in the cheeses made from RO milk compared with NONRO milk (Figure 3). One possible explanation is that cheese made from RO milk had higher residual lactose levels and thus more lactic acid was formed during ripening. Greater acid development in cheese can increase the rate of proteolysis during ripening (Lee et al., 2005).

\section{Rheological Properties of Cheeses}

The texture of RO LPM cheese during ripening was short and brittle. This was because of the low $\mathrm{pH}$

Table 3. Mean squares, probabilities, and degrees of freedom for factors that may influence the insoluble (INSOL) Ca content ${ }^{1}$ of Colby cheese

\begin{tabular}{lccc}
\hline Factor $^{2}$ & df & Mean squares & $P$-value \\
\hline Method & 1 & 91.43 & 0.11 \\
pH & 1 & 563.31 & $0.0025^{*}$ \\
Error & 7 & 26.60 & \\
& & & \\
Week & 5 & 167.21 & $<0.0001^{*}$ \\
Method $\times$ week & 5 & 21.27 & 0.15 \\
pH $\times$ week & 5 & 18.63 & 0.2 \\
Method $\times$ week $\times \mathrm{pH}$ & 5 & 10.44 & 0.51 \\
Error & 29 & 11.93 & \\
$\mathrm{R}^{2}$ & 0.87 & & \\
\hline
\end{tabular}

${ }^{1}$ INSOL Ca content as a percentage of total Ca in cheese.

${ }^{2}$ Methods used were concentration of milk by reverse osmosis and no concentration of milk; $\mathrm{pH}=$ different manufacturing $\mathrm{pH}$ (renneting and draining); Week $=$ cheese ripening time.

$* P<0.05$. 


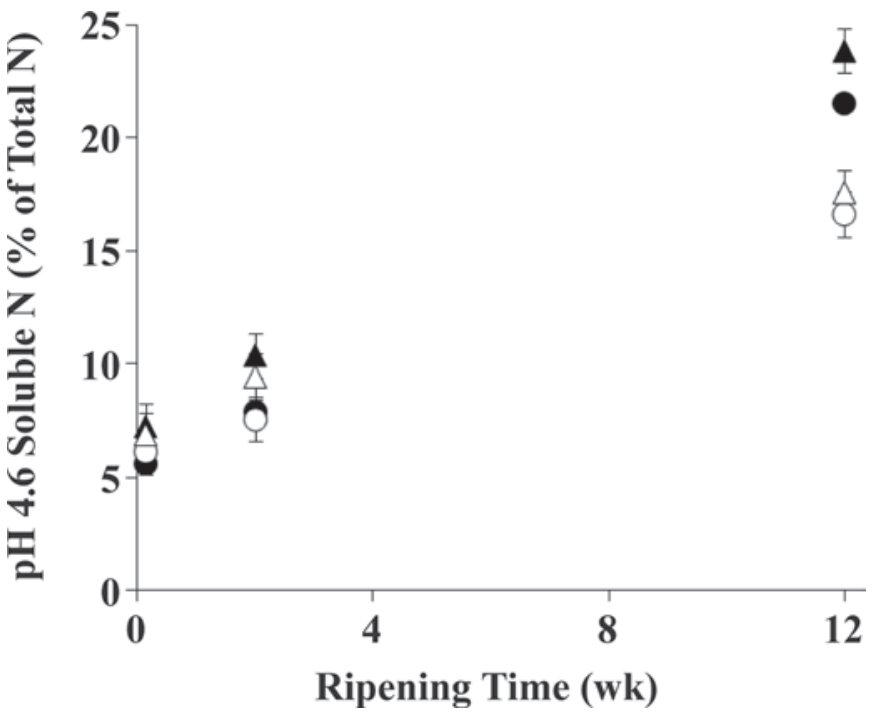

Figure 3. Changes in $\mathrm{pH} 4.6$ soluble nitrogen (as percentage of the total nitrogen) of Colby cheese made by using the RO, high $\mathrm{pH}$ method $(\bullet)$; the RO, low $\mathrm{pH}$ method $(\mathbf{\Delta})$; the NONRO, high $\mathrm{pH}$ method $(O)$; and the NONRO, low $\mathrm{pH}$ method $(\Delta)$. The data represent the means $(\mathrm{n}=3)$ and the error bars represent the standard deviations for each time point. $\mathrm{RO}=$ milk concentrated by reverse osmosis; NONRO $=$ milk not concentrated before cheese making.

$(\sim 4.9)$ of RO LPM cheese. Cheeses with low $\mathrm{pH}$ values have been reported to be brittle or short in many other studies; for example, Creamer et al. (1988).

During heating in the SAOR test, the maximum LT $\left(\mathbf{L} \mathbf{T}_{\max }\right)$ values observed as a function of ripening time are shown in Figure 4a. A higher $\mathrm{LT}_{\max }$ value indicates a greater propensity of cheese to melt and flow when heated (Lucey et al., 2003). At all ripening time points the LPM cheese from both RO and NONRO treatments had lower $\mathrm{LT}_{\max }$ values than the corresponding HPM treatment. This trend agrees with the lower $\mathrm{pH}$ values $(<5.0)$ obtained for both types of LPM cheeses (Figure 1). Lee et al. (2005) reported that the $\mathrm{LT}_{\max }$ values did not change (they remained $<1$ ) for cheese with $\mathrm{pH}$ values $<5.0$ during 3 mo of ripening. Except for the RO LPM cheese, the $\mathrm{LT}_{\max }$ values at 3 mo were significantly higher than those at $1 \mathrm{~d}$.

The temperature at $\mathrm{LT}_{\max }$ was approximately 70 to $75^{\circ} \mathrm{C}$ at $\mathrm{d} 1$ and then decreased to 60 to $65^{\circ} \mathrm{C}$ after 3 mo of ripening (data not shown). A decrease in the temperature at $\mathrm{LT}_{\max }$ during cheese ripening has been reported in several other studies (Lucey et al., 2003, 2005; Lee et al., 2005).

The DOF values, obtained from the UW Melt Profiler, significantly increased in all cheeses during the first 2 wk of ripening (Figure 4b). An increase in the DOF during the first few weeks of ripening has been reported in other studies (Lucey et al., 2005; Lee et al., 2005). The DOF hardly changed after 4 wk (Fig- ure 3b). During ripening, the DOF was lower in LPM cheese compared with HPM cheese from both RO and NONRO treatments.

It is likely that the limited meltability of RO LPM cheese (i.e., $\mathrm{LT}_{\max }$ values $<1$ and low $\mathrm{DOF}$ values) was because of the dominant effect of low $\mathrm{pH}$; that is, enhanced electrostatic attraction and reduced charge repulsion (Lee et al., 2005). The DOF of RO LPM cheese decreased between 2 and 4 wk of ripening, which coincided with a slight reduction in $\mathrm{pH}$ to $\sim 4.85$ (Figure 1). When the $\mathrm{pH}$ of cheese decreases below 5.0, very limited flow is observed (Pastorino et al., 2003; Lee et al., 2005).

Changes in $\mathrm{G}^{\prime}$ values during ripening are summarized in Table 4. In both NONRO cheeses, the $\mathrm{G}^{\prime}$ value determined at $5^{\circ} \mathrm{C}$ significantly increased during ripening (Table 4). There was no significant change in the $\mathrm{G}^{\prime}$ value determined at $5^{\circ} \mathrm{C}$ for the $2 \mathrm{RO}$ treatments. An increase in $\mathrm{G}^{\prime}$ value at $5^{\circ} \mathrm{C}$ of Cheddar cheese during ripening has been previously reported (Lucey et al., 2005). During ripening, the loss of INSOL Ca and ongoing proteolysis may facilitate greater rearrangement of casein molecules at low temperatures (swelling) where the hydrophobic interactions are weak (Lucey et al., 2005). McMahon et al. (2009) reported that the matrix of Feta cheese stored in brine at low temperatures exhibited swelling. This swelling of the matrix leads to increased casein-casein interactions (as determined from SAOR measurements), through $\mathrm{H}$-bond and electrostatic attractions (Lucey et al., 2003). This could explain the observed increase in $\mathrm{G}^{\prime}$ values determined at low temperature during ripening.

The $\mathrm{G}^{\prime}$ values at $5^{\circ} \mathrm{C}$ from all cheeses in this study was much higher than those $(<10 \mathrm{kPa})$ reported by Lucey et al. (2005) for Cheddar cheese (measured at the same frequencies). This could be due to differences in cheese $\mathrm{pH}$ between studies. The $\mathrm{pH}$ of Cheddar cheese studied by Lucey et al. (2005) ranged from 5.15 to 5.27, whereas in this study the $\mathrm{pH}$ of Colby cheese $\mathrm{pH}$ was much lower and ranged from 4.85 to 5.15 (Figure 1).

During ripening, RO LPM cheese had significantly higher $\mathrm{G}^{\prime}$ values at 5 and $40^{\circ} \mathrm{C}$ measuring temperatures compared with the other treatments. It should be noted that the RO LPM cheese also had the lowest $\mathrm{pH}$ value (i.e., $\mathrm{pH}<4.9$ ) of all treatments. Increased stiffness of cheese with low $\mathrm{pH}$ values $(<4.9)$ has been reported (Pastorino et al., 2003; Lee et al., 2005). There were no significant differences in $\mathrm{G}^{\prime}$ values at the 5 and $40^{\circ} \mathrm{C}$ measuring temperatures between the other cheese treatments during ripening.

During ripening, the $\mathrm{G}^{\prime}$ value at $80^{\circ} \mathrm{C}$ tended to decrease (except for NONRO LPM cheese, all the other treatments exhibited a significant reduction in the $\mathrm{G}^{\prime}$ value; Table 4). A decrease in the $\mathrm{G}^{\prime}$ value at $80^{\circ} \mathrm{C}$ 
Table 4. Storage modulus $\left(\mathrm{G}^{\prime}\right)^{1}$ of Colby cheeses made with milk concentrated by reverse osmosis (RO) or not concentrated (NONRO) as a function of ripening time for cheese tested at different temperatures from the small amplitude oscillatory rheology test (means \pm SD)

\begin{tabular}{|c|c|c|c|c|}
\hline \multirow[b]{2}{*}{$\mathrm{G}^{\prime}$ value tested at: } & \multicolumn{2}{|c|}{ NONRO treatment } & \multicolumn{2}{|c|}{ RO treatment } \\
\hline & $\mathrm{HPM}^{2}$ & $\mathrm{LPM}^{2}$ & $\mathrm{HPM}^{2}$ & $\mathrm{LPM}^{2}$ \\
\hline $5^{\circ} \mathrm{C}$ for cheese aged $1 \mathrm{~d}(\mathrm{kPa})$ & $160( \pm 32)^{\mathrm{B}, \mathrm{b}}$ & $170( \pm 6)^{\mathrm{B}, \mathrm{b}}$ & $220( \pm 100)^{\mathrm{A}, \mathrm{b}}$ & $380( \pm 51)^{\mathrm{A}, \mathrm{a}}$ \\
\hline $5^{\circ} \mathrm{C}$ for cheese aged $1 \mathrm{mo}(\mathrm{kPa})$ & $200( \pm 20)^{\mathrm{A}, \mathrm{b}}$ & $220( \pm 56)^{\mathrm{AB}, \mathrm{b}}$ & $170( \pm 38)^{\mathrm{A}, \mathrm{b}}$ & $330( \pm 43)^{\mathrm{A}, \mathrm{a}}$ \\
\hline $5^{\circ} \mathrm{C}$ for cheese aged $3 \mathrm{mo}(\mathrm{kPa})$ & $270( \pm 12)^{\mathrm{A}, \mathrm{b}}$ & $250( \pm 10)^{\mathrm{A}, \mathrm{b}}$ & $310( \pm 110)^{\mathrm{A}, \mathrm{b}}$ & $530( \pm 230)^{\mathrm{A}, \mathrm{a}}$ \\
\hline $40^{\circ} \mathrm{C}$ for cheese aged $1 \mathrm{~d}(\mathrm{kPa})$ & $5( \pm 0)^{\mathrm{AB}, \mathrm{b}}$ & $7( \pm 0)^{\mathrm{A}, \mathrm{b}}$ & $4( \pm 1.5)^{\mathrm{A}, \mathrm{b}}$ & $17( \pm 5)^{\mathrm{A}, \mathrm{a}}$ \\
\hline $40^{\circ} \mathrm{C}$ for cheese aged $1 \mathrm{mo}(\mathrm{kPa})$ & $4( \pm 1)^{\mathrm{B}, \mathrm{b}}$ & $6( \pm 4)^{\mathrm{A}, \mathrm{b}}$ & $3( \pm 0.7)^{\mathrm{A}, \mathrm{b}}$ & $14( \pm 0)^{\mathrm{B}, \mathrm{a}}$ \\
\hline $40^{\circ} \mathrm{C}$ for cheese aged $3 \mathrm{mo}(\mathrm{kPa})$ & $6( \pm 1)^{\mathrm{A}, \mathrm{b}}$ & $5( \pm 2)^{\mathrm{A}, \mathrm{b}}$ & $2( \pm 0.9)^{\mathrm{A}, \mathrm{b}}$ & $18( \pm 4)^{\mathrm{A}, \mathrm{a}}$ \\
\hline $80^{\circ} \mathrm{C}$ for cheese aged $1 \mathrm{~d}(\mathrm{~Pa})$ & $110( \pm 9)^{\mathrm{A}, \mathrm{a}}$ & $370( \pm 30)^{\mathrm{A}, \mathrm{a}}$ & $210( \pm 60)^{\mathrm{A}, \mathrm{a}}$ & $490( \pm 320)^{\mathrm{AB}, \mathrm{a}}$ \\
\hline $80^{\circ} \mathrm{C}$ for cheese aged $1 \mathrm{mo}(\mathrm{Pa})$ & $20( \pm 4)^{\mathrm{C}, \mathrm{c}}$ & $300( \pm 2)^{\mathrm{A}, \mathrm{b}}$ & $64( \pm 4)^{\mathrm{B}, \mathrm{c}}$ & $700( \pm 4)^{\mathrm{A}, \mathrm{a}}$ \\
\hline $80^{\circ} \mathrm{C}$ for cheese aged $3 \mathrm{mo}(\mathrm{Pa})$ & $48( \pm 6)^{\mathrm{B}, \mathrm{b}}$ & $150( \pm 3)^{\mathrm{A}, \mathrm{a}}$ & $56( \pm 3)^{\mathrm{B}, \mathrm{b}}$ & $51( \pm 2)^{\mathrm{B}, \mathrm{b}}$ \\
\hline
\end{tabular}

${ }^{\mathrm{A}-\mathrm{C}}$ Different uppercase letters in a treatment, at the same measuring temperature, but different ages, indicate that values are significantly different $(P<0.05)$.

${ }^{\mathrm{a}-\mathrm{c}}$ Different lowercase letters in the same row indicate that values are significantly different $(P<0.05)$.

${ }^{1}$ Note that the $\mathrm{G}^{\prime}$ values for test temperatures of 5 and $40^{\circ} \mathrm{C}$ are in $\mathrm{kPa}$, whereas the $\mathrm{G}^{\prime}$ units at $80^{\circ} \mathrm{C}$ are in $\mathrm{Pa}$

${ }^{2} \mathrm{HPM}=$ high $\mathrm{pH}$ method; LPM $=$ low $\mathrm{pH}$ method.

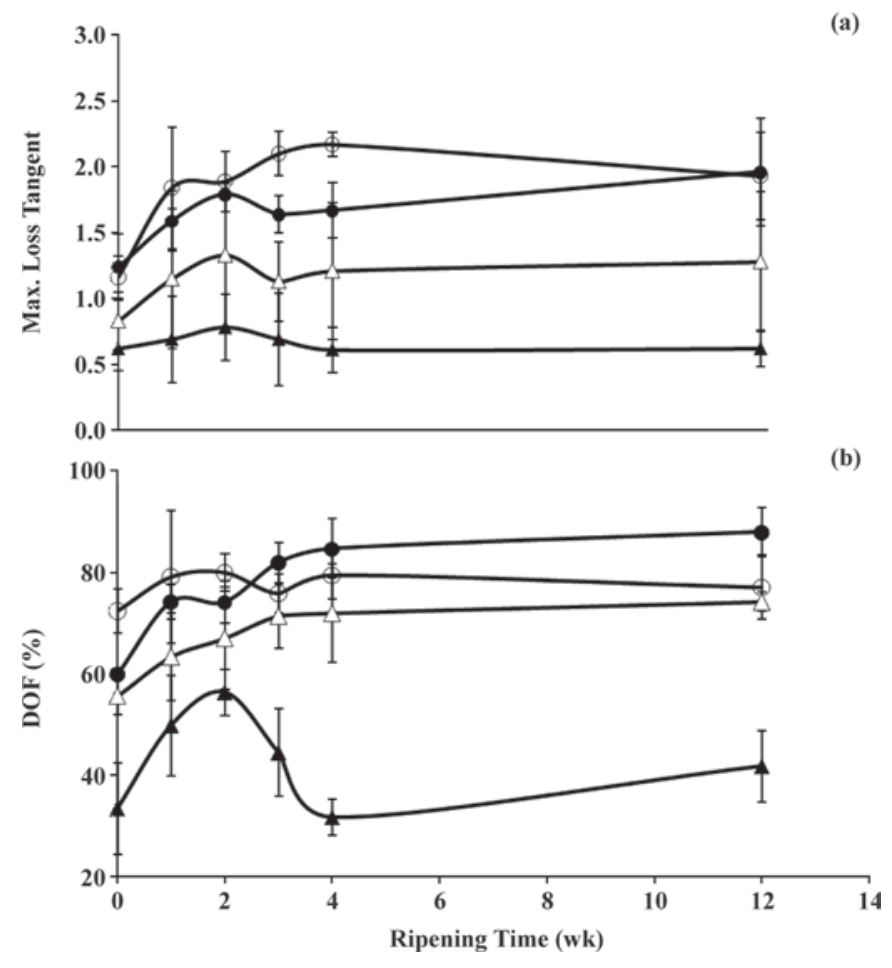

Figure 4. Changes in a) the maximum loss tangent from the small amplitude oscillatory rheology test and b) degree of flow (DOF) from UW Melt Profiler test (Wisconsin Center for Dairy Research, Madison) for Colby cheese made by using the RO, high $\mathrm{pH}$ method $(\bullet)$; the RO, low $\mathrm{pH}$ method $(\boldsymbol{\Delta})$; the NONRO, high $\mathrm{pH}$ method $(\mathrm{O})$; and the NONRO, low $\mathrm{pH}$ method $(\Delta)$. The data represent the means $(\mathrm{n}=3)$ and the error bars represent the standard deviations for each time point. $\mathrm{RO}=$ milk concentrated by reverse osmosis; $\mathrm{NONRO}=$ milk not concentrated before cheese making. during ripening was reported in Cheddar cheese (Lucey et al., 2005).

\section{Correlations}

Cheese $\mathrm{pH}$ values and INSOL Ca contents of cheese during aging were significantly positively correlated in both RO and NONRO treatments $(P<0.0001$; Table $5)$. Cheese $\mathrm{pH}$ was significantly positively correlated with $\mathrm{LT}_{\max }$ value $(P<0.0001, \mathrm{r}=0.84)$ and with the DOF $(P<0.0001)$. This result is consistent with the reduction in melt/flow with a decrease in $\mathrm{pH}$ observed in many studies.

There were significantly positive correlations between the INSOL Ca content of cheese and the temperature at the $\mathrm{LT}_{\max }$ in cheeses $(P<0.0001, \mathrm{r}=0.72)$. The $\mathrm{LT}_{\max }$ value was highly positively correlated with the DOF in cheeses $(P<0.0001, \mathrm{r}=0.69)$; the $\mathrm{LT}_{\max }$ and meltability of has been previously reported to be positively correlated (Ustunol et al., 1994; Mounsey and O'Riordan, 1999; Lucey et al., 2005). Lower total and INSOL Ca content of cheese gives softer and more easily flowable cheeses (e.g., Lucey and Fox, 1993; Joshi et al., 2003). The $\mathrm{G}^{\prime}$ values at 5,40 , or $80^{\circ} \mathrm{C}$ were not significantly correlated with INSOL Ca content of cheese, but the $\mathrm{G}^{\prime}$ values at $80^{\circ} \mathrm{C}$ were negatively correlated with the $\mathrm{pH}$ and $\mathrm{LT}_{\max }$ values.

\section{CONCLUSIONS}

Lower manufacturing $\mathrm{pH}$ values resulted in greater loss of INSOL Ca phosphate, a reduction in buffering capacity of curd, and lower cheese $\mathrm{pH}$. Washing was effective at reducing the residual lactose content of 
Table 5. Pearson correlation coefficients between different cheese parameters ${ }^{1}$ during ripening of cheeses made with milk concentrated by reverse osmosis and not concentrated

\begin{tabular}{|c|c|c|c|c|c|}
\hline Parameter & Cheese $\mathrm{pH}$ & $\mathrm{LT}_{\max }$ & Temp. at $\mathrm{LT}_{\max }$ & $\mathrm{G}^{\prime}$ value at $80^{\circ} \mathrm{C}$ & DOF \\
\hline $\begin{array}{l}\text { INSOL Ca } \\
\text { Cheese pH } \\
\mathrm{LT}_{\max }\end{array}$ & $0.52^{* * * *}$ & $0.84^{* * * *}$ & $\begin{array}{l}0.72^{* * * *} \\
0.56^{* * * *}\end{array}$ & $\begin{array}{l}-0.48^{* * * *} \\
-0.53^{* * * *}\end{array}$ & $\begin{array}{l}0.58^{* * * *} \\
0.69^{* * * *}\end{array}$ \\
\hline
\end{tabular}

${ }^{1} \mathrm{DOF}=$ degree of flow; $\mathrm{G}^{\prime}=$ storage modulus; INSOL $\mathrm{Ca}=$ percentage insoluble $\mathrm{Ca}$ as a percentage of total $\mathrm{Ca} ; \mathrm{LT}_{\max }=$ maximum loss tangent

$* * * * P<0.0001$.

cheese, even in RO-concentrated milk. Curd washing also resulted in cheeses that hardly changed in $\mathrm{pH}$ during ripening. A significant decrease in INSOL Ca of cheese was observed during ripening even though the $\mathrm{pH}$ of all cheeses changed little $(<0.1 \mathrm{pH}$ unit). Cheese with very low $\mathrm{pH}$ values $(<4.9)$ exhibited limited meltability during ripening probably because of enhanced electrostatic attraction between caseins. Cheese makers often standardize their cheese milk with skim milk powder, which results in an increase in the lactose levels. Cheese makers often use lower renneting or draining $\mathrm{pH}$ values in these fortified milks to improve meltability. The use of low renneting, draining, and salting $\mathrm{pH}$ values results in Colby cheese with very low cheese $\mathrm{pH}$ values. The use of low manufacturing $\mathrm{pH}$ values reduces the buffering capacity of curd and can lead to acidic and poorly meltable cheese. Curd washing could not compensate for the use of low renneting or draining $\mathrm{pH}$ values for Colby cheese made from concentrated milks. Use of standardization agents such as ultrafiltration retentates would be recommended because of their lower lactose content.

\section{ACKNOWLEDGMENTS}

The authors appreciate the funding of Dairy Management Inc. (Rosemont, IL) and the Wisconsin Milk Marketing Board (Madison, WI). The authors thank Bill Hoesly and Gene Barmore of the Wisconsin Center for Dairy Research for cheesemaking and reverse osmosis processing, respectively.

\section{REFERENCES}

Creamer, L. K., J. Gilles, and R. C. Lawrence. 1988. Effect of pH on the texture of Cheddar and Colby cheese. N.Z. J. Dairy Sci. Technol. 23:23-35.

Fox, P. F., T. P. Guinee, T. M. Cogan, and P. L. H. McSweeney. 2000. Fundamentals of Cheese Science. Aspen Publishers Inc., Gaithersburg, MD.

Guinee, T. P., E. P. Feeney, M. A. E. Auty, and P. F. Fox. 2002. Effect of $\mathrm{pH}$ and calcium concentration on some textural and functional properties of Mozzarella cheese. J. Dairy Sci. 85:1655-1669.

Hassan, A., M. E. Johnson, and J. A. Lucey. 2004. Changes in the proportions of soluble and insoluble calcium during the ripening of Cheddar cheese. J. Dairy Sci. 87:854-862.
Huffman, L. M., and T. Kristoffersen. 1984. Role of lactose in Cheddar cheese manufacturing and ripening. N.Z. J. Dairy Sci. Tech. 19:151-162.

IDF. 1997. Bovine rennet. Determination of total milk-clotting activity 157A:1997. International Dairy Federation, Brussels, Belgium.

IDF. 2003. Determination of calcium, sodium, potassium and magnesium contents-Atomic absorption spectrometric method; 119:2003. International Dairy Federation, Brussels, Belgium.

IDF. 2005. Cheese-Determination of rheological properties by uniaxial compression at constant displacement rate; Draft Standard 205:2005. International Dairy Federation, Brussels, Belgium.

Johnson, M. E., and J. A. Lucey. 2006. Calcium: A key factor in controlling cheese functionality. Aust. J. Dairy Technol. 61:147153.

Joshi, N. S., K. Muthukumarappan, and R. I. Dave. 2003. Understanding the role of calcium in functionality of part-skim Mozzarella cheese. J. Dairy Sci. 86:1918-1926.

Kosikowski, F. V., and V. V. Mistry. 1997. Cheese and Fermented Milk Foods. 3rd ed. F. V. Kosikowski LLC, Westport, CT.

Kuchroo, C. N., and P. F. Fox. 1982. Soluble nitrogen in Cheddar cheese; Comparison of extraction procedures. Milchwissenschaft $37: 331-335$.

Lee, M.-R., M. E. Johnson, and J. A. Lucey. 2005. Impact of modifications in acid development on the insoluble calcium content and rheological properties of Cheddar cheese. J. Dairy Sci. 88:3798-3809.

Lolkema, H. 1994. Cheese yield used as an instrument for process control-Experience in Friesland, the Netherlands. Pages 156-197 in Factors Affecting the Yield of Cheese. Special Issue No. 9301. International Dairy Federation, Brussels, Belgium.

Lucey, J. A., and P. F. Fox. 1993. Importance of calcium and phosphate in cheese manufacture: A review. J. Dairy Sci. 76:1714-1724.

Lucey, J. A., M. E. Johnson, and D. S. Horne. 2003. Perspectives on the basis of the rheology and texture properties of cheese. J. Dairy Sci. 86:2725-2743

Lucey, J. A., R. Mishra, A. Hassan, and M. E. Johnson. 2005. Rheological and calcium equilibrium changes during ripening of Cheddar cheese. Int. Dairy J. 15:645-653.

Marshall, R. T. 1992. Standard Methods for the Examination of Dairy Products. 16th ed. American Public Health Association, Washington, DC.

McMahon, D. J., M. M. Motawee, and W. R. McManus. 2009 Influence of brine concentration and temperature on composition, microstructure, and yield of Feta cheese. J. Dairy Sci. 92:4169 4179

Metzger, L. E., D. M. Barbano, and P. S. Kindstedt. 2001. Effect of milk preacidification on low fat Mozzarella cheese: III. Post-melt chewiness and whiteness. J. Dairy Sci. 84:1357-1366.

Monib, A. M. M. F. 1962. The calcium-paracaseinate-phosphate complex under conditions similar to those in cheese. Meded. Landbouw. Wageningen 62:1-76.

Mounsey, J. S., and E. D. O'Riordan. 1999. Empirical and dynamic rheological data correlation to characterize melt characteristics of imitation cheese. J. Food Sci. 64:701-703.

Muthukumarappan, K., Y.-C. Wang, and S. Gunasekaran. 1999. Estimating softening point of cheeses. J. Dairy Sci. 82:22802286 
O'Mahony, J. A., J. A. Lucey, and P. L. H. McSweeney. 2005. Chymosin-mediated proteolysis, calcium solubilization, and texture development during the ripening of Cheddar cheese. J. Dairy Sci. 88:3101-3114.

Pastorino, A. J., C. L. Hansen, and D. J. McMahon. 2003. Effect of pH on the chemical composition and structure-function relationships of Cheddar cheese. J. Dairy Sci. 86:2751-2760.

Pyne, G. T., and T. C. A. McGann. 1960. The colloidal calcium phosphate of milk. 2. Influence of citrate. J. Dairy Res. 27:9-17.

SAS Institute. 2001. Release 8.2. SAS Institute Inc., Cary, NC.

Shakeel-Ur-Rehman, D. Waldron, and P. F. Fox. 2004. Effect of modifying lactose concentration in cheese curd on proteolysis and in quality of Cheddar cheese. Int. Dairy J. 14:591-597.

Swearingen, P. A., D. E. Adams, and T. L. Lensmire. 2004. Factors affecting calcium lactate and whey expulsion defects in Cheddar cheese. J. Dairy Sci. 87:574-582.

Thierry, A., D. Salvant-Brunard, M.-M. Madec, F. Michel, and J.L. Maubois. 1998. Affinage de l'Emmental: Dynamique des populations bacterienne et evolution de la composition de la phase aquese. Lait 78:521-542.

Thomas, T. D., and K. N. Pearce. 1981. Influence of salt on lactose fermentation and proteolysis in Cheddar cheese. N.Z. J. Dairy Sci. Technol. 16:253-259.
Upreti, P., and L. E. Metzger. 2007. Influence of calcium and phosphorus, lactose, and salt-to moisture ratio on Cheddar cheese quality: $\mathrm{pH}$ changes during ripening. J. Dairy Sci. 90:1-12.

Ustunol, Z., K. Kawachi, and J. Steffe. 1994. Arnott test correlates with dynamic rheological properties for determining Cheddar cheese meltability. J. Food Sci. 59:970-971.

Van Den Berg, V. G., and E. De Vries. 1974. Der Zusammenhang zwischen den faktoren, die den $\mathrm{pH}$ von Käse beeinflussen. Milchwissenschaft 29:214-218.

Van Slyke, L. L., and W. V. Price. 1949. Cheese; A Treatise on the Manufacture of American Cheddar Cheese and Some Other Varieties. Orange Judd Publishing Co. Inc., New York, NY.

Walstra, P., J. T. M. Wouters, and T. J. Geurts. 2006. Dairy Science and Technology. 2nd ed. CRC Press, Boca Raton, FL.

Wilson, H. L., and G. W. Reinbold. 1965. American Cheese Varieties. Pfizer Cheese Monograph Series. Vol. 2. Pfizer and Co. Inc., New York, NY.

Yun, J. J., D. M. Barbano, P. S. Kindstedt, and K. L. Larose. 1995. Mozzarella cheese: impact of whey $\mathrm{pH}$ at draining on chemical, composition, proteolysis, and functional properties. J. Dairy Sci. $78: 1-7$. 